\title{
Effects of Climate Change on Grassland Biodiversity and Productivity: The Need for a Diversity of Models
}

\author{
Marcel van Oijen ${ }^{1, *(\mathbb{D})}$, Gianni Bellocchi ${ }^{2}$ and Mats Höglind ${ }^{3}$ \\ 1 Centre for Ecology \& Hydrology, Bush Estate, Penicuik EH26 0QB, UK \\ 2 Grassland Ecosystem Research Unit (UREP), National Institute of Agricultural Research (INRA), \\ 63000 Clermont-Ferrand, France; gianni.bellocchi@inra.fr \\ 3 Norwegian Institute of Bioeconomy Research, 4353 Klepp Stasjon, Norway; mats.hoglind@nibio.no \\ * Correspondence: mvano@ceh.ac.uk
}

Received: 14 December 2017; Accepted: 31 January 2018; Published: 2 February 2018

\begin{abstract}
There is increasing evidence that the impact of climate change on the productivity of grasslands will at least partly depend on their biodiversity. A high level of biodiversity may confer stability to grassland ecosystems against environmental change, but there are also direct effects of biodiversity on the quantity and quality of grassland productivity. To explain the manifold interactions, and to predict future climatic responses, models may be used. However, models designed for studying the interaction between biodiversity and productivity tend to be structurally different from models for studying the effects of climatic impacts. Here we review the literature on the impacts of climate change on biodiversity and productivity of grasslands. We first discuss the availability of data for model development. Then we analyse strengths and weaknesses of three types of model: ecological, process-based and integrated. We discuss the merits of this model diversity and the scope for merging different model types.
\end{abstract}

Keywords: data needs; empirical models; integrated models; process-based models; review

\section{Introduction}

Permanent grasslands are often hot spots of biodiversity [1], which contributes to the temporal stability of their services. The variety of plant species present in grasslands is strongly influenced by long-term management practices [2], with livestock grazing being the major driving force affecting vegetation dynamics, species distribution and landscape-scale biodiversity in addition to forage quantity and quality [3]. Biodiversity, encompassing variation within species and across landscapes, may be crucial for the longer-term resilience of ecosystem functions and the services that they underpin [4]. Biodiversity is intimately connected to ecosystem services through various relationships [5], with species-rich communities tending to perform better than any individual species.

Biodiversity-ecosystem functioning relationships are affected by the number and identities of species, their evenness within the community, their functional traits, and their interactions. If species loss can be compensated by other species contributing similarly to functioning, the role of individual species may shift with environmental change [6]. Abiotic change then leads to biotic change and vice versa, and different species can contribute most to any given ecosystem process at different points in time and space [7]. However, there are limits to species redundancy, and high biodiversity is needed to maintain the many processes operating in multi-functioning ecosystems $[8,9]$.

As concepts of ecosystem functioning have evolved, work has broadened to encompass biodiversity loss within and between trophic levels [10]. This work has benefited from studies of food webs and more widely of ecological networks [11]. However, Novak et al. [12] concluded that such studies can only provide limited predictive capacity while our knowledge of the strengths of 
interactions between species remains poor. The need for increased predictive capacity is pressing, as the world's ecosystems undergo unprecedented changes with species being lost from a wide range of ecosystems and trophic levels [13] and there is a need to consider the role that models can play. In particular, the challenges that grassland systems are facing today imply that aspects related to plant diversity cannot be ignored in modelling studies. Grassland models thus need to consider the nutritional value of multi-species swards [14], the differing herbage intake of grazing animals between mixtures and pure stands [15], the dependence of milk protein content on the botanical composition of swards [16], the beneficial effect of legumes on the nitrogen economy of multi-species swards [15], and the supporting and regulating services (e.g., pollination, pest control, drought resistance) provided by multi-species swards [17]. Of primary importance is the need for models to account for the complex and variable relationship between grassland biodiversity and productivity. If primary productivity is not used by grazers or humans, then it may sustain larger biodiversity [18], although some degree of grazing may stimulate biodiversity [19]. Further, reducing management intensity (e.g., fertilisation) in grasslands reduces livestock productivity but may enhance the quality of meat [20]. So trade-offs between biodiversity and the way grassland productivity is exploited exist, and climate change may affect how we prioritise one or the other (e.g., [21-23]). We need modelling tools to negotiate these trade-offs (e.g., [24-27]).

The literature on grassland modelling is extensive. Google Scholar finds over 2 million articles that include the terms 'model' as well as 'grass' or 'grassland', and 1670 of those have the terms in their title; Web of Science finds 1403 thus titled papers (information retrieved on 20 November 2017). We therefore focus our review on categories of grassland models rather than on specific models. Our primary interest here is in modelling the responses of grasslands of varying degrees of biodiversity to climate change. Of course, the climate not only affects grassland biodiversity and productivity but is itself affected by grassland dynamics at large spatial scales. Grasslands, like all vegetation, affect climate via their albedo and greenhouse gas balance, and may play an important role in mitigating climate change. Vegetation effects on the atmosphere are represented in the latest generation of GCMs (Global Climate Models), but are not further discussed here.

We shall consider both static and dynamic modelling, and modelling aimed at explaining observations as well as modelling aimed at predicting the impact of environmental change. We start off with an overview of data that are available for model development. We then review empirical, process-based and integrated grassland modelling approaches. These are reviewed separately, before discussing their relative strengths and weaknesses, and the scope for using elements from one model type in another. A summary of this model overview is provided in Table 1 . We conclude the paper with a brief outlook toward the future use of new types of data and modelling approaches. 
Table 1. Summary of model types.

\begin{tabular}{|c|c|c|c|c|c|}
\hline & \multirow[t]{2}{*}{ Empirical Models } & \multicolumn{3}{|c|}{ Process-Based Models } & \multirow[t]{2}{*}{ Integrated Models } \\
\hline & & Ecological & Biogeochemical & Agricultural & \\
\hline Characteristics & $\begin{array}{l}\text { Statistical models } \\
\text { (regression etc.) }\end{array}$ & $\begin{array}{l}\text { Small models focusing on biotic } \\
\text { interactions; elegant mathematics }\end{array}$ & $\begin{array}{l}\text { Parameter-rich models of cycling of } \\
\text { carbon, nutrients, water }\end{array}$ & $\begin{array}{l}\text { Parameter-rich models of } \\
\text { phenology and yield formation }\end{array}$ & $\begin{array}{l}\text { Hierarchical models that } \\
\text { include process-based models } \\
\text { and human agents }\end{array}$ \\
\hline Static/Dynamic & Static & Dynamic & Dynamic & Dynamic & Dynamic \\
\hline Strengths & $\begin{array}{l}\text { Flexibility; ease of use; } \\
\text { spatial heterogeneity }\end{array}$ & $\begin{array}{l}\text { Explaining general ecological patterns } \\
\text { including species interactions }\end{array}$ & $\begin{array}{c}\text { Long-term prediction of } \\
\text { biogeochemical cycles and soil pools }\end{array}$ & $\begin{array}{l}\text { Short-term prediction of } \\
\text { productivity }\end{array}$ & $\begin{array}{l}\text { Comprehensive; scope for } \\
\text { assessing policy }\end{array}$ \\
\hline Weaknesses & $\begin{array}{l}\text { Non-predictive outside } \\
\text { calibration range }\end{array}$ & $\begin{array}{l}\text { Abiotic effects and spatial } \\
\text { heterogeneity poorly accounted for }\end{array}$ & $\begin{array}{l}\text { Limited capacity for yield forecasting; } \\
\text { no spatial heterogeneity/biodiversity }\end{array}$ & $\begin{array}{l}\text { No long-term predictive } \\
\text { capacity; no spatial } \\
\text { heterogeneity/biodiversity }\end{array}$ & $\begin{array}{l}\text { Weaknesses inherited from } \\
\text { component models; difficult } \\
\text { to parameterize and test }\end{array}$ \\
\hline Examples & {$[18,28-34]$} & [35-44] & [45-50] & {$[51-55]$} & {$[56,57]$} \\
\hline
\end{tabular}




\section{Data and Inferences from Experimental and Observational Studies}

A large body of data from observational studies and from agricultural and ecological experimentation has been collected for grasslands. Data cover both dry and wet areas across wide latitudinal, longitudinal and altitudinal ranges. Most of the ground-breaking experiments on vegetation biodiversity from the 1980s onward were and are being carried out in grasslands because of the convenient size and lifespan of grassland species [58]. These experiments have primarily focused on the relation between the number of grass species in swards and the magnitude and stability of primary productivity (e.g., [59]), with some experiments looking at the impact of water or nutrient availability on this relationship [60], and interactions with mowing [61,62]. In a meta-analysis of 44 grassland biodiversity experiments [63], it was found that different grassland species tended to complement each other, leading to increased productivity in polycultures compared to monocultures. Hector et al. [64], analysing data from eight sites, found that grassland biodiversity enhanced the stability of productivity over time primarily because of asynchrony in population development. In most of these experiments, full ground cover was established. In grassland experiments with low ground cover, biodiversity still conferred stability but productivity depended more on ground cover than on species richness [65]. Also, experiments in Germany by Assaf et al. [66] suggest that biodiversity has a stronger effect on productivity in unmanaged than in managed grasslands. De Boeck et al. [67] found by experiment that warming may increase the detrimental effect of species loss on grassland productivity in temperate climates. Soussana \& Lüscher [68] reviewed literature showing that elevated $\mathrm{CO}_{2}$ is likely to benefit legumes and forbes more than grasses. In temperature-limited environments of high-latitudes, warming is likely to benefit legumes more than grasses during the temperate growing season [15,69], whereas increased nitrogen deposition will disfavour legumes [60]. However, it is still highly uncertain how warming will affect the winter survival of different grassland species [70], and the overall impact of warming and interactions with atmospheric $\mathrm{CO}_{2}$ concentration on grassland biodiversity and productivity at high latitudes is highly uncertain.

Agricultural experimentation on grasslands has tended to focus on the impact of abiotic factors and management on yield and quality of forage. However, experiments on grass-legume interactions (typically using only a single grass species and a single clover species) have been carried out for many decades, including interactions with temperature and nitrogen supply [71-73], grazers [15] and FACE-studies of responses of grasses and legumes to elevated $\mathrm{CO}_{2}$ and fertilisation [74]. Also, there have been experiments examining the effect on cow milk production and ruminant meat quality of grazing the animals on grasslands of differing species composition and richness (e.g., [75-77] and studies mentioned in the Introduction).

In short, there is a fair amount of data available for the further development of models aiming to explain or predict the mutual effects of biodiversity and productivity (e.g., [78]), and the impact of grazing thereon (e.g., [79]). In contrast, data are still scarce on how climate change, i.e., changes in weather variables rather than $\mathrm{CO}_{2}$, may affect these relationships (but see the aforementioned [69]). Also lacking are data that may help explain observed relationships between biodiversity and productivity in grasslands, such as data on soil dynamics-changes in carbon, nutrient and water pools, and the spatial heterogeneity of these pools [80]. Such soil data are essential if we want to model long-term impacts of changes in biodiversity. In the 9-year long Jena Experiment (Jena, Germany), soil carbon concentration increase was observed to be highly correlated with sown plant species richness [81]. In particular, the presence of legumes negatively affected soil carbon concentration while other plant functional groups did not influence it, and any increase in carbon storage was mainly limited by the integration of new carbon into soil from fine root turnover and less by the decomposition of existing soil carbon. Long-term data on managed grasslands have also been produced in resampling studies to detect changes in various diversity indices, likely resulting from grazing and fertilization [82-84], but the studies lack information about the history of environmental and anthropogenic drivers. 
Increasingly, grassland data are becoming available that cover sizeable areas. Tall tower eddy covariance measurements with large spatial footprints and remote sensing allow coverage of large areas at increasing spatial resolution. These data are used to calibrate grassland models aimed at estimating greenhouse gas fluxes and biomass $[85,86]$ but are generally not linked to any biodiversity research. Jing et al. [87] demonstrated the importance of belowground biodiversity for ecosystem multifunctionality at 60 sites on the Tibetan Plateau, covering an area of over one million $\mathrm{km}^{2}$. They pointed out the need for more experimental work to assess the degree to which climate modulates the links between belowground biodiversity and ecosystem functionality.

\section{Empirical Modelling (Static)}

Analysis of biodiversity data has most often been carried out using static empirical models that relate response variables to driving variables in a non-dynamic way. Empirical modelling increasingly goes beyond standard linear regression methods, although those are still found useful for productivity-diversity modelling [28]. Multivariate regression models (e.g., based on constrained ordination) are commonly used in community ecology of grasslands to explain gradients of species or functional composition by a set of climatic, edaphic and agricultural variables [33]. Newer methods used in grassland modelling include generalised linear and additive mixed models (GLM, GLMM, GAMM; e.g., [29]), nonlinear species-interaction models [30] and structural equation models [31]. Lee et al. [32] used mixed-effects modelling to combine the results of grassland experiments with projections of future $\mathrm{CO}_{2}$ and nitrogen deposition, to identify areas where productivity may increase and biodiversity decrease. Other examples of empirical models include statistical modelling of livestock productivity effects on grassland biodiversity [18] and Amiri et al.'s [34] geospatial model for optimising choice of grazing area given spatial heterogeneity in vulnerability to drought and erosion.

These statistical techniques allow flexible representation of main and interactive effects. However, as all empirical models, they are valuable as descriptive and analytical tools rather than as means for prediction. Extrapolation of empirical models to new conditions (e.g., due to climate change) remains largely speculative, and we focus the remainder of this review on process-based models.

\section{Process-Based Modelling (Dynamic)}

We define process-based models (PBMs) as dynamic models which explicitly represent processes and mechanisms underlying aspects of biodiversity and productivity. PBMs for grasslands vary in complexity (number of inputs, parameters, processes, feedbacks) and domain of application (spatiotemporal scale, conditions for which the models are designed and calibrated). Any subdivision of models is to some extent subjective, but we distinguish three categories of PBM here: (1) ecological models; (2) biogeochemical models; (3) agricultural models. These represent three largely distinct communities of scientists, with different research questions and modelling preferences. Baker \& Viglizzo [88] produced a useful evaluation of rangeland models worldwide, focusing on how the models simulated the interaction between plants and grazers. They used a slightly different categorization of models than we do here, with decision support systems and integrated models being grouped together with other dynamic models.

\subsection{Ecological Modelling}

Ecological models tend to be relatively small models, with few variables and parameters, and often expressed using elegant mathematics. A common aim for these models is to study general ecological patterns rather than questions for specific ecosystems. An example is the model prediction that moderate grazing may increase biodiversity compared to ungrazed lands $[35,36]$. Hunt [37] used a matrix population model to show that sheep grazing may lead to local extinction of shrub species. More recently, individual-based models have been presented to simulate the trade-offs among plant functional traits and their plasticity in response to environmental changes. May et al. [38] presented an individual-based grassland model that included root- and shoot-competition and was able to 
reproduce grazing reversal: the finding that grazing increases biodiversity in productive environments but reduces it at unproductive sites. A newer version of the same model was used in a further study [39] showing the effects of grazing and landscape fragmentation on the persistence of different grassland community types over periods of hundreds of years. Maire et al. [40,41] made explicit simulations of the mechanisms according to which species interact within communities, linking inter-specific competition to species traits. Further examples are the three simple models of Tilman et al. [42], each of which provides an explanation of the positive effect of biodiversity on grassland productivity through interspecific variation in resource use. Loreau et al. [43] produced a simple model showing how spatial heterogeneity in species distribution may provide stability at large spatial scales.

There are various competing ecological biodiversity theories [89], some of which are mainly expressed verbally without quantitative modelling, and several of which have not been empirically tested [90]. Any specific ecological model thus remains, to some extent, a speculative implementation of one of these theories. Another limitation of ecological models for the study of biodiversity (including recent ones e.g., [44]) is that they tend to focus on intrinsic population dynamical processes (demography, competition) rather than on the abiotic environment [91]. This reduces their usability for climate change impact research.

\subsection{Biogeochemical Modelling}

Biogeochemical models tend to be rich in parameters and variables, simulating in detail the connections between soil, vegetation, possibly heterotrophs, and atmosphere through the various biogeochemical cycles of carbon, water, and nutrients [92]. A typical application of these models is to predict, at fairly low spatial resolution, the long-term response of biogeochemical cycles to environmental change. An elegant example is the work of Cannell and Thornley [45] who showed that the response of nitrogen-poor grasslands to elevated $\mathrm{CO}_{2}$ may, after an initial delay, in the long-term exceed the response of more fertile grasslands, because of higher $\mathrm{N}$-retention in the soil. The spatial resolution is generally matched by a simplified scheme of ecosystem categories, based on the concept of plant functional type (PFT). For example, European grasslands, despite huge variation in biodiversity, may all be lumped in one PFT representing "temperate grassland consisting of C3 species". Soil decomposition processes tend to be represented in great detail, with multiple soil pools for each biogeochemical cycle, but with minimal representation of spatial heterogeneity.

One example of a biogeochemical model is PaSim, which is used to simulate the interaction between greenhouse gas emissions, growth and grazing in managed grasslands [46,47], and other examples are included in an ensemble of models studied by Sándor et al. [48] and Ehrhardt et al. [49]. More complex examples of biogeochemical modelling are formed by Dynamic Global Vegetation Models (DGVMs; [50]), which simulate possible transitions between PFTs driven by environmental change. PFT-based biogeochemical models such as DGVMs cannot be used to study the role of biodiversity within grasslands, but they can be used to study the stability of grasslands in the face of climate change. However, recent studies in biogeography try to bridge biodiversity and ecosystem science and can help implementing integrated frameworks to connect key questions in both disciplines, e.g., on the one hand the dynamics of determinants of species and plant trait assembly and, on the other hand, the effects of climate, land use and biodiversity changes on biogeochemical cycles [93].

\subsection{Agricultural Modelling}

Agricultural models mostly do not focus on long-term changes in biogeochemical cycles. Rather, they focus on yield prediction and yield analysis. However, the distinction between the agricultural and biogeochemical model types is not absolute, as some models aim to simulate productivity and biogeochemistry to similar accuracy. Soils are often represented using fewer pools and processes in agricultural models than in biogeochemical ones, but plant processes may be represented more fully, e.g., grass-legume interaction [51], cold hardening and winter mortality of tillers [52] and the impacts of pests and diseases. Models accounting for biotic stress factors have mainly been reported for arable crops (e.g., [53]), whereas examples for grassland are rare. 
Models of grassland dynamics based on the explicit simulation of growth and development of different species in a community and of the competition among them can reflect detailed knowledge of the underlying system. Such models tend to be implemented as three-dimensional, individual-based [54] or even sub-individual-based [55] competition models. The complexity and parameter-richness of these models makes them difficult to initialize and parameterize.

The application of agricultural grassland models is therefore generally limited to communities with only a few species and restricted simulation areas. However, the scope for grassland models of intermediate complexity based on agricultural models for single species but incorporating simplified expressions of the effects of competing species on sward dynamics is currently being investigated [94].

\subsection{Strengths and Weaknesses of Process-Based Modelling}

The three PBM types have different strengths. Ecological models explain general patterns of biodiversity, productivity and stability. Biogeochemical models predict long-term changes to carbon, water and nutrient cycles. Agricultural models predict yields, feeding value and possible losses due to abiotic and biotic factors. To predict the impact of climate change on grasslands, including the role of biodiversity, we arguably need all three: there is value in model diversity.

However, there are common weaknesses in all these PBMs. Spatial heterogeneity, both above- and belowground, is generally ignored or oversimplified. The impacts of grazing are not well simulated. For example, observations that loss of grazing animals may lead to loss of biodiversity at the landscape scale [95], are difficult to reproduce for any of these PBMs. However, Peringer et al. [96], using a spatially explicit PBM, were able to explain observed impacts of grazing on the persistence of pastures in a silvopastoral landscape. There is increasing evidence that the relationship between grazing and biodiversity is highly complex and affected by nutrient availability. Bullock et al. [97] found that long-term sheep grazing could benefit or hamper grassland species depending on the timing and intensity of the grazing and on the functional traits of the plant species. No PBM capable of explaining or predicting these intricacies currently exists.

Another common weakness of PBMs is that they do not represent processes of physiological and genetic adaptation of grassland species to environmental change. There has been work on relating observed genetic variation amongst grassland cultivars to parameters of PBMs with a view toward ideotype design in plant breeding [98] but natural rather than man-made genetic change is not addressed by PBMs. The predictive capacity of the models is hampered by such incomplete process representation but also by other model structural errors and lack of data for parameterisation. There is a need for model comparison and model development in a probabilistic framework $[99,100]$. That will allow rigorous uncertainty quantification-see the example of comparison and uncertainty analysis for three grassland models by Korhonen et al. [101].

\section{Integrated Modelling}

Integrated models, like PBMs, are dynamic models, but with the additional characteristic that interactions with human agents are explicitly simulated. So a PBM could form the non-human ecosystem component of an integrated model. A modern approach to integrated modelling is by means of probabilistic networks (graphical models, e.g., Bayesian belief networks for ecosystem services; [56]). Typically, integrated models are aimed at policy-makers rather than managers of grasslands (who, as a group, are likely to appear as agents in the integrated models). An integrated model for grasslands is the Sustainability and Organic Livestock Model (SOL-Model) which is "especially designed for an integrated analysis of environmental and socio-economic aspects and their inter-linkages" [57].

The strengths of integrated modelling are its comprehensiveness (by including human activities) and, for the network approach, the probabilistic thinking that facilitates uncertainty analysis, risk analysis and decision-support. However, integrated models do propagate the weaknesses, discussed above, of any ecological, biogeochemical or agricultural models that they incorporate, and their 
complexity may hamper the application of probabilistic techniques for calibration, uncertainty assessment and risk analysis [102].

\section{Discussion}

\subsection{Modelling Aim and Model Types}

This review has focused on one important aim of grassland modelling: to predict the impact of climate change on biodiversity-productivity relationships. In this context, a key question is the following: Will biodiversity loss make grasslands less resilient to climate change in general and extreme events in particular? Although there has been provided some experimental evidence for this (e.g., increased drought resistance at higher biodiversity: [103]), we have not found that current grassland models are able to reproduce these findings. Continued model development thus remains necessary.

Given that our aim involves environmental change, dynamic models seem more appropriate tools than static empirical ones, and we shall focus on PBMs rather than integrated models. But which type of PBM to use? We believe that the answer depends on whether the PBM is used for short- or long-term prediction.

\subsection{Modelling for Short-Term Prediction}

In the case of short-term prediction, biodiversity is not likely to change much and can be treated as a fixed boundary condition, not dynamically simulated. We suggest that the way forward in this situation is to start from agricultural models but to add the mechanisms through which a given degree of biodiversity protects grassland from diseases, extreme weather events, erosion and other threats. This implies enriching the agricultural grassland PBMs with elements from ecological and biogeochemical models. However, the assumption of constant biodiversity is unlikely to be adequate for the long-term perspective of climate change.

\subsection{Modelling for Long-Term Prediction}

For long-term prediction, biodiversity must be considered a dynamic variable. Biogeochemical models may be the model type of choice here, given their strength in long-term prediction [45], but elements from ecological models need to be added to simulate the biodiversity dynamics. For such model development we need more data on currently poorly quantified aspects of biodiversity, such as its role in erosion prevention, tolerance to extreme events, disease resistance, soil decomposition; see e.g., [104,105]. Moreover, elements from agricultural models (in particular the impact of management-fertilisation, irrigation, harvesting etc. and grazing on growth and yield) need to be included in the modelling to allow prediction of future food security.

Climate change is expected to increase drought risks for Mediterranean grasslands [106]. This may prompt us to investigate the use of modelling approaches developed for non-European semi-arid grazing lands. For example, Benie et al. [86] modelled the impact of grazing intensity on erosion risk in semi-arid grasslands in the Sahel. For grasslands in cold temperate regions, long-term predictions should also take into account the modifying effect of low temperature related stress on vegetation composition and productivity [52,70].

The process of further developing biogeochemical models using elements from ecological and agricultural models may lead to large and unwieldy models, difficult to parameterise. Therefore, rather than explicitly simulating the growth of many different grassland species and their competition, we could consider adding only a biodiversity metric (e.g., the Shannon index; [107]) as a dynamically varying state-variable in the model. Such simplification would need to be tested carefully, the more so because long-term prediction may require us to consider other aspects of biodiversity than just plant species richness, e.g., soil biodiversity [87]. For example, persistence of microbial and faunal biodiversity may be required to maintain organic matter decomposition capacity of soils [108-111]. 


\subsection{The Need for Model Diversity}

We conclude that, for estimating the impact of climate change impacts on the biodiversityproductivity relationship in managed grasslands, we shall need process-based modelling as outlined above, with models of different kinds depending on the time-frame and spatial extent of prediction. However, PBMs emphasise the biophysical aspects of the system. For wider goals, such as policy making, integrated models rather than PBMs will be needed, to represent the role of human agents. Rather than incorporating complex PBMs in integrated models, it may be best to keep the model types separate and only include simplified representations of the biophysics possibly based on analysis using PBMs in policy-oriented integrated models.

A difficult methodological issue-alluded to at several points in this review-concerns model complexity. The modelling studies considered here address goals that are typically kept separate: explaining and predicting both biodiversity and productivity, as well as their interactions, under climate change. Given our grown understanding of these processes and interactions, more detail could be represented in models, but this would increase our data needs for model parameterization and testing. The optimum in this trade-off will depend on the specific goals of each study, the available data and the methods employed for model calibration and analysis [98], and general recommendations are not feasible. The best approach may be to maintain model diversity and stimulate comparisons between different models and modelling paradigms.

\section{Conclusions}

In conclusion, we believe that modelling the interaction between climate change and the biodiversity-productivity relationship in grasslands will benefit from model diversity, allowing where needed the merging of elements from ecological, biogeochemical and agricultural models. This will take various forms depending on the spatiotemporal scale of application. Summary models derived from such modelling work (e.g., in the form of generically re-usable components, after Confalonieri et al. [94]), rather than the PBMs themselves, may then be incorporated in integrated models to support policy-making.

Model development will require new data on mechanisms underlying changes in biodiversity, in particular data on spatial heterogeneity of species distribution and soil characteristics. In this respect, we need data analysis methods that allow interpretation of eddy-covariance flux measurements and remote sensing measurements (albedo, NDVI-derived estimates of LAI and biomass; see Wachendorf et al. [112] for a review of available methods and their potential application in grassland research) in terms of biodiversity. Such data (or proxies obtained from model analysis, e.g., [113]) are needed to link models across spatial scales (both upscaling and downscaling). A promising example is the work of Gaitán et al. [114] who found that satellite observations showed the least amount of drought-induced reduction of NDVI in those Patagonian rangelands that were species-rich.

Increased application of probabilistic methods (such as in Bayesian calibration of PBMs or graphical network modelling for ecosystem services) will be needed to quantify uncertainties associated with model predictions and to support risk analysis [102,106]. Network modelling will also facilitate analysis of the trade-offs and synergies between productivity, biodiversity and the various other ecosystem services not examined here [115].

The increasing availability of data at various spatial and temporal scales, the existing diversity of dynamic models, and the fast development of probabilistic methods that provide the link between data and models-all these, in our view, portent well for the future of grassland modelling as a tool for explaining and predicting the impact of climate change on biodiversity and productivity.

Acknowledgments: This work was carried out as part of the knowledge-hub Modelling European Agriculture with Climate Change for Food Security (MACSUR). M.v.O. thanks the Natural Environment Research Council in the U.K. for funding his participation in MACSUR and the Norwegian Institute of Bioeconomy Research (NIBIO) for additional support. G.B. thanks the metaprogramme Adaptation of Agriculture and Forests to Climate Change 
(AAFCC) of the French National Institute for Agricultural Research (INRA). M.H. thanks the Research Council of Norway for funding his participation in MACSUR. We also acknowledge the valuable comments from reviewers of this paper.

Author Contributions: M.v.O. carried out the initial analysis of the literature and wrote the first draft of the paper; G.B. and M.H. added references and improved the analysis; all three authors co-wrote the final text.

Conflicts of Interest: The authors declare no conflict of interest.

\section{References}

1. Marriott, C.; Fothergill, M.; Jeangros, B.; Scotton, M.; Louault, F. Long-term impacts of extensification of grassland management on biodiversity and productivity in upland areas: A review. Agronomie 2004, 24, 447-462. [CrossRef]

2. Myers, N.; Mittermeier, R.A.; Mittermeier, C.G.; da Fonseca, G.A.B.; Kent, J. Biodiversity hotspots for conservation priorities. Nature 2000, 403, 853. [CrossRef] [PubMed]

3. Henkin, Z.; Perevolotsky, A.; Sternberg, M. Vulnerability of Mediterranean grasslands to climate change: What can we learn from a long-term experiment. Options Méditerr. Sér. A Sém. Méditerr. 2010, 92, 167-174.

4. Oliver, T.H.; Heard, M.S.; Isaac, N.J.B.; Roy, D.B.; Procter, D.; Eigenbrod, F.; Freckleton, R.; Hector, A.; Orme, C.D.L.; Petchey, O.L.; et al. Biodiversity and Resilience of Ecosystem Functions. Trends Ecol. Evol. 2015, 30, 673-684. [CrossRef] [PubMed]

5. Mace, G.M.; Norris, K.; Fitter, A.H. Biodiversity and ecosystem services: A multilayered relationship. Trends Ecol. Evol. 2012, 27, 19-26. [CrossRef] [PubMed]

6. Fetzer, I.; Johst, K.; Schäwe, R.; Banitz, T.; Harms, H.; Chatzinotas, A. The extent of functional redundancy changes as species' roles shift in different environments. Proc. Natl. Acad. Sci. USA 2015, 112, 14888-14893. [CrossRef] [PubMed]

7. Isbell, F.; Calcagno, V.; Hector, A.; Connolly, J.; Harpole, W.S.; Reich, P.B.; Scherer-Lorenzen, M.; Schmid, B.; Tilman, D.; van Ruijven, J.; et al. High plant diversity is needed to maintain ecosystem services. Nature 2011, 477, 199. [CrossRef] [PubMed]

8. Hector, A.; Bagchi, R. Biodiversity and ecosystem multifunctionality. Nature 2007, 448, 188. [CrossRef] [PubMed]

9. Gamfeldt, L.; Hillebrand, H.; Jonsson, P.R. Multiple Functions Increase the Importance of Biodiversity for Overall Ecosystem Functioning. Ecology 2008, 89, 1223-1231. [CrossRef] [PubMed]

10. Duffy, J.E.; Cardinale, B.J.; France, K.E.; McIntyre, P.B.; Thébault, E.; Loreau, M. The functional role of biodiversity in ecosystems: Incorporating trophic complexity. Ecol. Lett. 2007, 10, 522-538. [CrossRef] [PubMed]

11. Ings, T.C.; Montoya, J.M.; Bascompte, J.; Blüthgen, N.; Brown, L.; Dormann, C.F.; Edwards, F.; Figueroa, D.; Jacob, U.; Jones, J.I.; et al. Review: Ecological networks beyond food webs. J. Anim. Ecol. 2009, 78, 253-269. [CrossRef] [PubMed]

12. Novak, M.; Wootton, J.T.; Doak, D.F.; Emmerson, M.; Estes, J.A.; Tinker, M.T. Predicting community responses to perturbations in the face of imperfect knowledge and network complexity. Ecology 2011, 92, 836-846. [CrossRef] [PubMed]

13. Ceballos, G.; Ehrlich, P.R.; Barnosky, A.D.; García, A.; Pringle, R.M.; Palmer, T.M. Accelerated modern humaninduced species losses: Entering the sixth mass extinction. Sci. Adv. 2015, 1, e1400253. [CrossRef] [PubMed]

14. Delaby, L.; Baumont, R.; Peccatte, J.R.; Aufrère, J.; Peyraud, J.L. Description and prediction of multi-species pasture nutritive value across the grazing season. Grassland in a changing world. In Proceedings of the 23rd General Meeting of the European Grassland Federation, Kiel, Germany, 29 August-2 September 2010; pp. 485-487.

15. Lüscher, A.; Mueller-Harvey, I.; Soussana, J.F.; Rees, R.M.; Peyraud, J.L. Potential of legume-based grasslandlivestock systems in Europe: A review. Grass Forage Sci. 2014, 69, 206-228. [CrossRef] [PubMed]

16. Stergiadis, S.; Leifert, C.; Seal, C.J.; Eyre, M.D.; Larsen, M.K.; Slots, T.; Nielsen, J.H.; Butler, G. A 2-year study on milk quality from three pasture-based dairy systems of contrasting production intensities in Wales. J. Agric. Sci. 2015, 153, 708-731. [CrossRef] 
17. Rutledge, S.; Wall, A.M.; Mudge, P.L.; Troughton, B.; Campbell, D.I.; Pronger, J.; Joshi, C.; Schipper, L.A. The carbon balance of temperate grasslands part I: The impact of increased species diversity. Agric. Ecosyst. Environ. 2017, 239, 310-323. [CrossRef]

18. Alkemade, R.; Reid, R.S.; van den Berg, M.; de Leeuw, J.; Jeuken, M. Assessing the impacts of livestock production on biodiversity in rangeland ecosystems. Proc. Natl. Acad. Sci. USA 2013, 110, 20900-20905. [CrossRef] [PubMed]

19. Aguiar, M.R. Biodiversity in grasslands. Current changes and future scenarios. In Grasslands: Developments, Opportunities, Perspectives; Science Publishers, Inc.: Enfield, NH, USA, 2005.

20. Bullock, J.M.; Jefferson, R.G.; Blackstock, T.H.; Pakeman, R.J.; Emmett, B.A.; Pywell, R.J.; Grime, J.P.; Silvertown, J. Semi-Natural Grasslands; Technical Report; UN Environment World Conservation Monitoring Centre (UNEP-WCMC): Cambridge, UK, 2011.

21. Gottfried, M.; Pauli, H.; Futschik, A.; Akhalkatsi, M.; Barančok, P.; Benito Alonso, J.L.; Coldea, G.; Dick, J.; Erschbamer, B.; Fernández Calzado, M.R.; et al. Continent-wide response of mountain vegetation to climate change. Nat. Clim. Chang. 2012, 2,111-115. [CrossRef]

22. Gavazov, K.; Peringer, A.; Buttler, A.; Gillet, F.; Spiegelberger, T. Dynamics of Forage Production in Pasture-woodlands of the Swiss Jura Mountains under Projected Climate Change Scenarios. Ecol. Soc. 2013, 18. [CrossRef]

23. Ergon, Å.; Seddaiu, G.; Korhonen, P.; Virkajärvi, P.; Bellocchi, G.; Jørgensen, M.; Østrem, L.; Reheul, D.; Volaire, F. How can forage production in Nordic and Mediterranean Europe adapt to the challenges and opportunities arising from climate change? Eur. J. Agron. 2018, 92, 97-106. [CrossRef]

24. Soussana, J.F.; Graux, A.I.; Tubiello, F.N. Improving the use of modelling for projections of climate change impacts on crops and pastures. J. Exp. Bot. 2010, 61, 2217-2228. [CrossRef] [PubMed]

25. Cammarano, D.; Rivington, M.; Matthews, K.; Miller, D.; Bellocchi, G. Implications of climate model biases and downscaling on crop model simulated climate change impacts. Eur. J. Agron. 2017, 88, 63-75. [CrossRef]

26. Pulina, A.; Lai, R.; Salis, L.; Seddaiu, G.; Roggero, P.P.; Bellocchi, G. Modelling pasture production and soil temperature, water and carbon fluxes in Mediterranean grassland systems with the Pasture Simulation model. Grass Forage Sci. 2017, 1-12. [CrossRef]

27. Sándor, R.; Picon-Cochard, C.; Martin, R.; Louault, F.; Klumpp, K.; Borras, D.; Bellocchi, G. Plant acclimation to temperature: Developments in the Pasture Simulation model. Field Crops Res. 2017. [CrossRef]

28. Bai, Y.; Wu, J.; Pan, Q.; Huang, J.; Wang, Q.; Li, F.; Buyantuyev, A.; Han, X. Positive linear relationship between productivity and diversity: Evidence from the Eurasian Steppe. J. Appl. Ecol. 2007, 44, 1023-1034. [CrossRef]

29. Lavorel, S.; Grigulis, K.; Lamarque, P.; Colace, M.-P.; Garden, D.; Girel, J.; Pellet, G.; Douzet, R. Using plant functional traits to understand the landscape distribution of multiple ecosystem services. J. Ecol. 2011, 99, 135-147. [CrossRef]

30. Connolly, J.; Bell, T.; Bolger, T.; Brophy, C.; Carnus, T.; Finn, J.A.; Kirwan, L.; Isbell, F.; Levine, J.; Lüscher, A.; et al. An improved model to predict the effects of changing biodiversity levels on ecosystem function. J. Ecol. 2013, 101, 344-355. [CrossRef]

31. Grace, J.B.; Michael Anderson, T.; Smith, M.D.; Seabloom, E.; Andelman, S.J.; Meche, G.; Weiher, E.; Allain, L.K.; Jutila, H.; Sankaran, M.; et al. Does species diversity limit productivity in natural grassland communities? Ecol. Lett. 2007, 10, 680-689. [CrossRef] [PubMed]

32. Lee, M.; Manning, P.; Rist, J.; Power, S.A.; Marsh, C. A global comparison of grassland biomass responses to $\mathrm{CO}_{2}$ and nitrogen enrichment. Philos. Trans. R. Soc. B Biol. Sci. 2010, 365, 2047-2056. [CrossRef] [PubMed]

33. Mauchamp, L.; Mouly, A.; Badot, P.-M.; Gillet, F. Impact of management type and intensity on multiple facets of grassland biodiversity in the French Jura Mountains. Appl. Veg. Sci. 2014, 17, 645-657. [CrossRef]

34. Amiri, F.; bin Mohamed Shariff, A.R.; Tabatabaie, T.; Pradhan, B. A geospatial model for the optimization grazing management in semi-arid rangeland of Iran. Arabian J. Geosci. 2013, 7, 1101-1114. [CrossRef]

35. Milchunas, D.; Sala, O.E.; Lauenroth, W. A generalized model of the effects of grazing by large herbivores on grassland community structure. Am. Nat. 1988, 132, 87-106. [CrossRef]

36. Bai, Y.; Abouguendia, Z.; Redmann, R.E. Relationship between plant species diversity and grassland condition. J. Range Manag. 2001, 54, 177-183. [CrossRef]

37. Hunt, L. Heterogeneous grazing causes local extinction of edible perennial shrubs: A matrix analysis. J. Appl. Ecol. 2001, 38, 238-252. [CrossRef] 
38. May, F.; Grimm, V.; Jeltsch, F. Reversed effects of grazing on plant diversity: The role of below-ground competition and size symmetry. Oikos 2009, 118, 1830-1843. [CrossRef]

39. Weiss, L.; Pfestorf, H.; May, F.; Körner, K.; Boch, S.; Fischer, M.; Müller, J.; Prati, D.; Socher, S.A.; Jeltsch, F. Grazing response patterns indicate isolation of semi-natural European grasslands. Oikos 2014, 123, 599-612. [CrossRef]

40. Maire, V.; Gross, N.; Hill, D.; Martin, R.; Wirth, C.; Wright, I.J.; Soussana, J.-F. Disentangling Coordination among Functional Traits Using an Individual-Centred Model: Impact on Plant Performance at Intra- and Inter-Specific Levels. PLoS ONE 2013, 8, e77372. [CrossRef] [PubMed]

41. Maire, V.; Soussana, J.-F.; Gross, N.; Bachelet, B.; Pagès, L.; Martin, R.; Reinhold, T.; Wirth, C.; Hill, D. Plasticity of plant form and function sustains productivity and dominance along environment and competition gradients. A modeling experiment with Gemini. Ecol. Model. 2013, 254, 80-91. [CrossRef]

42. Tilman, D.; Lehman, C.L.; Thomson, K.T. Plant diversity and ecosystem productivity: Theoretical considerations. Proc. Natl. Acad. Sci. USA 1997, 94, 1857-1861. [CrossRef] [PubMed]

43. Loreau, M.; Mouquet, N.; Gonzalez, A. Biodiversity as spatial insurance in heterogeneous landscapes. Proc. Natl. Acad. Sci. USA 2003, 100, 12765-12770. [CrossRef] [PubMed]

44. De Mazancourt, C.; Isbell, F.; Larocque, A.; Berendse, F.; De Luca, E.; Grace, J.B.; Haegeman, B.; Wayne Polley, H.; Roscher, C.; Schmid, B.; et al. Predicting ecosystem stability from community composition and biodiversity. Ecol. Lett. 2013, 16, 617-625. [CrossRef] [PubMed]

45. Cannell, M.G.R.; Thornley, J.H.M. N-poor ecosystems may respond more to elevated $\left[\mathrm{CO}_{2}\right]$ than N-rich ones in the long term. A model analysis of grassland. Glob. Chang. Biol. 1998, 4, 431-442. [CrossRef]

46. Vuichard, N.; Ciais, P.; Viovy, N.; Calanca, P.; Soussana, J.-F. Estimating the greenhouse gas fluxes of European grasslands with a process-based model: 2. Simulations at the continental level. Glob. Biogeochem. Cycles 2007, 21. [CrossRef]

47. Ma, S.; Lardy, R.; Graux, A.-I.; Ben Touhami, H.; Klumpp, K.; Martin, R.; Bellocchi, G. Regional-scale analysis of carbon and water cycles on managed grassland systems. Environ. Model. Softw. 2015, 72, 356-371. [CrossRef]

48. Sándor, R.; Barcza, Z.; Acutis, M.; Doro, L.; Hidy, D.; Köchy, M.; Minet, J.; Lellei-Kovács, E.; Ma, S.; Perego, A.; et al. Multi-model simulation of soil temperature, soil water content and biomass in Euro-Mediterranean grasslands: Uncertainties and ensemble performance. Eur. J. Agron. 2017, 88, $22-40$. [CrossRef]

49. Ehrhardt, F.; Soussana, J.-F.; Bellocchi, G.; Grace, P.; McAuliffe, R.; Recous, S.; Sándor, R.; Smith, P.; Snow, V.; de Antoni Migliorati, M.; et al. Assessing uncertainties in crop and pasture ensemble model simulations of productivity and $\mathrm{N}_{2} \mathrm{O}$ emissions. Glob. Chang. Biol. 2017, 24, e603-e616. [CrossRef] [PubMed]

50. Baudena, M.; Dekker, S.C.; van Bodegom, P.M.; Cuesta, B.; Higgins, S.I.; Lehsten, V.; Reick, C.H.; Rietkerk, M.; Scheiter, S.; Yin, Z.; et al. Forests, savannas, and grasslands: Bridging the knowledge gap between ecology and Dynamic Global Vegetation Models. Biogeosciences 2015, 12, 1833-1848. [CrossRef]

51. Soussana, J.-F.; Maire, V.; Gross, N.; Bachelet, B.; Pagès, L.; Martin, R.; Hill, D.; Wirth, C. Gemini: A grassland model simulating the role of plant traits for community dynamics and ecosystem functioning. Parameterization and evaluation. Ecol. Model. 2012, 231, 134-145. [CrossRef]

52. Höglind, M.; Van Oijen, M.; Cameron, D.; Persson, T. Process-based simulation of growth and overwintering of grassland using the BASGRA model. Ecol. Model. 2016, 335, 1-15. [CrossRef]

53. Donatelli, M.; Magarey, R.D.; Bregaglio, S.; Willocquet, L.; Whish, J.P.M.; Savary, S. Modelling the impacts of pests and diseases on agricultural systems. Agric. Syst. 2017, 155, 213-224. [CrossRef] [PubMed]

54. Munier-Jolain, N.M.; Guyot, S.H.M.; Colbach, N. A 3D model for light interception in heterogeneous crop:Weed canopies: Model structure and evaluation. Ecol. Model. 2013, 250, 101-110. [CrossRef]

55. Clark, B.; Bullock, S. Shedding light on plant competition: Modelling the influence of plant morphology on light capture (and vice versa). J. Theor. Biol. 2007, 244, 208-217. [CrossRef] [PubMed]

56. Landuyt, D.; Broekx, S.; D’hondt, R.; Engelen, G.; Aertsens, J.; Goethals, P.L.M. A review of Bayesian belief networks in ecosystem service modelling. Environ. Model. Softw. 2013, 46, 1-11. [CrossRef]

57. Food and Agriculture Organization (FAO). Sustanability and Organic Livestock-Model (Sol-M); Food and Agriculture Organization: Rome, Italy, 2012; p. 6.

58. Davis, T.H. Biography of David Tilman. Proc. Natl. Acad. Sci. USA 2004, 101, 10851-10853. [CrossRef] [PubMed] 
59. Tilman, D.; Wedin, D.; Knops, J. Productivity and sustainability influenced by biodiversity in grassland ecosystems. Nature 1996, 379, 718-720. [CrossRef]

60. Niu, D.; Yuan, X.; Cease, A.J.; Wen, H.; Zhang, C.; Fu, H.; Elser, J.J. The impact of nitrogen enrichment on grassland ecosystem stability depends on nitrogen addition level. Sci. Total Environ. 2017. [CrossRef] [PubMed]

61. Yang, H.; Jiang, L.; Li, L.; Li, A.; Wu, M.; Wan, S. Diversity-dependent stability under mowing and nutrient addition: Evidence from a 7-year grassland experiment. Ecol. Lett. 2012, 15, 619-626. [CrossRef] [PubMed]

62. Zhang, Y.; Loreau, M.; He, N.; Zhang, G.; Han, X. Mowing exacerbates the loss of ecosystem stability under nitrogen enrichment in a temperate grassland. Funct. Ecol. 2017, 31, 1637-1646. [CrossRef] [PubMed]

63. Cardinale, B.J.; Wright, J.P.; Cadotte, M.W.; Carroll, I.T.; Hector, A.; Srivastava, D.S.; Loreau, M.; Weis, J.J. Impacts of plant diversity on biomass production increase through time because of species complementarity. Proc. Natl. Acad. Sci. USA 2007, 104, 18123-18128. [CrossRef] [PubMed]

64. Hector, A.; Hautier, Y.; Saner, P.; Wacker, L.; Bagchi, R.; Joshi, J.; Scherer-Lorenzen, M.; Spehn, E.M.; Bazeley-White, E.; Weilenmann, M.; et al. General stabilizing effects of plant diversity on grassland productivity through population asynchrony and overyielding. Ecology 2010, 91, 2213-2220. [CrossRef] [PubMed]

65. Ji, S.; Geng, Y.; Li, D.; Wang, G. Plant coverage is more important than species richness in enhancing aboveground biomass in a premature grassland, northern China. Agric. Ecosyst. Environ. 2009, 129, 491-496. [CrossRef]

66. Assaf, T.A.; Beyschlag, W.; Isselstein, J. The Relationship between Plant Diversity and Productivity in Natural and in Managed Grasslands. Appl. Ecol. Environ. Res. 2011, 9, 157-166. [CrossRef]

67. De Boeck, H.; Lemmens, C.; Gielen, B.; Bossuyt, H.; Malchair, S.; Carnol, M.; Merckx, R.; Ceulemans, R.; Nijs, I. Combined effects of climate warming and plant diversity loss on above- and below-ground grassland productivity. Environ. Exp. Bot. 2007, 60, 95-104. [CrossRef]

68. Soussana, J.-F.; Lüscher, A. Temperate grasslands and global atmospheric change: A review. Grass Forage Sci. 2007, 62, 127-134. [CrossRef]

69. Cantarel, A.A.M.; Bloor, J.M.G.; Soussana, J.-F. Four years of simulated climate change reduces above-ground productivity and alters functional diversity in a grassland ecosystem. J. Veg. Sci. 2013, 24, 113-126. [CrossRef]

70. Rapacz, M.; Ergon, Å.; Höglind, M.; Jørgensen, M.; Jurczyk, B.; Østrem, L.; Rognli, O.A.; Tronsmo, A.M. Overwintering of herbaceous plants in a changing climate. Still more questions than answers. Plant Sci. 2014, 225, 34-44. [CrossRef] [PubMed]

71. Davidson, I.A.; Robson, M.J.; Drennan, D.S.H. Effect of Temperature and Nitrogen Supply on the Growth of Perennial Ryegrass and White Clover. 1. Carbon and Nitrogen Economies of Mixed Swards at Low Temperature. Ann. Bot. 1986, 57, 697-708. [CrossRef]

72. Woledge, J. Competition between grass and clover in spring as affected by nitrogen fertiliser. Ann. Appl. Biol. 1988, 112, 175-186. [CrossRef]

73. Nesheim, L.; Boller, B.C. Nitrogen fixation by white clover when competing with grasses at moderately low temperatures. Plant Soil 1991, 133, 47-56. [CrossRef]

74. Zanetti, S.; Hartwig, U.A.; van Kessel, C.; Lüscher, A.; Hebeisen, T.; Frehner, M.; Fischer, B.U.; Hendrey, G.R.; Blum, H.; Nösberger, J. Does nitrogen nutrition restrict the $\mathrm{CO}_{2}$ response of fertile grassland lacking legumes? Oecologia 1997, 112, 17-25. [CrossRef] [PubMed]

75. Steinshamn, H.; Höglind, M.; Havrevoll, Ø.; Saarem, K.; Lombnæs, I.H.; Steinheim, G.; Svendsen, A. Performance and meat quality of suckling calves grazing cultivated pasture or free range in mountain. Livest. Sci. 2010, 132, 87-97. [CrossRef]

76. Willems, H.; Kreuzer, M.; Leiber, F. Vegetation-type effects on performance and meat quality of growing Engadine and Valaisian Black Nose sheep grazing alpine pastures. Livest. Sci. 2013, 151, 80-91. [CrossRef]

77. Roca-Fernández, A.I.; Peyraud, J.L.; Delaby, L.; Delagarde, R. Pasture intake and milk production of dairy cows rotationally grazing on multi-species swards. Animal 2016, 10, 1448-1456. [CrossRef] [PubMed]

78. Brophy, C.; Finn, J.A.; Lüscher, A.; Suter, M.; Kirwan, L.; Sebastià, M.-T.; Helgadóttir, Á.; Baadshaug, O.H.; Bélanger, G.; Black, A.; et al. Major shifts in species' relative abundance in grassland mixtures alongside positive effects of species diversity in yield: A continental-scale experiment. J. Ecol. 2017, 105, 1210-1222. [CrossRef] 
79. Batáry, P.; Báldi, A.; Erdos, S. Grassland versus non-grassland bird abundance and diversity in managed grasslands: Local, landscape and regional scale effects. In Vertebrate Conservation and Biodiversity; Hawksworth, D.L., Bull, A.T., Eds.; Springer: Dordrecht, The Netherlands, 2006; pp. 45-55, ISBN 978-1-4020-6320-6.

80. Ives, A.R.; Carpenter, S.R. Stability and Diversity of Ecosystems. Science 2007, 317, 58-62. [CrossRef] [PubMed]

81. Lange, M.; Eisenhauer, N.; Sierra, C.A.; Bessler, H.; Engels, C.; Griffiths, R.I.; Mellado-Vázquez, P.G.; Malik, A.A.; Roy, J.; Scheu, S.; et al. Plant diversity increases soil microbial activity and soil carbon storage. Nat. Commun. 2015, 6. [CrossRef] [PubMed]

82. Homburger, H.; Hofer, G. Diversity change of mountain hay meadows in the Swiss Alps. Basic Appl. Ecol. 2012, 13, 132-138. [CrossRef]

83. Wesche, K.; Krause, B.; Culmsee, H.; Leuschner, C. Fifty years of change in Central European grassland vegetation: Large losses in species richness and animal-pollinated plants. Biol. Conserv. 2012, 150, $76-85$. [CrossRef]

84. Gillet, F.; Mauchamp, L.; Badot, P.-M.; Mouly, A. Recent changes in mountain grasslands: A vegetation resampling study. Ecol. Evol. 2016, 6, 2333-2345. [CrossRef] [PubMed]

85. Ciais, P.; Soussana, J.F.; Vuichard, N.; Luyssaert, S.; Don, A.; Janssens, I.A.; Piao, S.L.; Dechow, R.; Lathière, J.; Maignan, F.; et al. The greenhouse gas balance of European grasslands. Biogeosci. Discuss. 2010, 7, 5997-6050. [CrossRef]

86. Bénié, G.B.; Kaboré, S.S.; Goïta, K.; Courel, M.F. Remote sensing-based spatio-temporal modeling to predict biomass in Sahelian grazing ecosystem. Ecol. Model. 2005, 184, 341-354. [CrossRef]

87. Jing, X.; Sanders, N.J.; Shi, Y.; Chu, H.; Classen, A.T.; Zhao, K.; Chen, L.; Shi, Y.; Jiang, Y.; He, J.-S. The links between ecosystem multifunctionality and above- and belowground biodiversity are mediated by climate. Nat. Commun. 2015, 6, 8159. [CrossRef] [PubMed]

88. Baker, B.; Viglizzo, E. Rangeland and Livestock. In Handbook on Methods for Climate Change Impact Assessment and Adaptation Strategies; Feenstra, J.F., Burton, I., Smith, J.B., Tol, R.S.J., Eds.; UNEP: Amsterdam, The Netherlands, 1998; pp. 1-34.

89. Hautier, Y.; Tilman, D.; Isbell, F.; Seabloom, E.W.; Borer, E.T.; Reich, P.B. Anthropogenic environmental changes affect ecosystem stability via biodiversity. Science 2015, 348, 336-340. [CrossRef] [PubMed]

90. Rillig, M.C.; Kiessling, W.; Borsch, T.; Gessler, A.; Greenwood, A.D.; Hofer, H.; Joshi, J.; Schröder, B.; Thonicke, K.; Tockner, K.; et al. Biodiversity research: Data without theory-Theory without data. Conservation 2015, 3, 20. [CrossRef]

91. Loreau, M.; Naeem, S.; Inchausti, P.; Bengtsson, J.; Grime, J.P.; Hector, A.; Hooper, D.U.; Huston, M.A.; Raffaelli, D.; Schmid, B.; et al. Biodiversity and Ecosystem Functioning: Current Knowledge and Future Challenges. Science 2001, 294, 804-808. [CrossRef] [PubMed]

92. Brilli, L.; Bechini, L.; Bindi, M.; Carozzi, M.; Cavalli, D.; Conant, R.; Dorich, C.D.; Doro, L.; Ehrhardt, F.; Farina, R.; et al. Review and analysis of strengths and weaknesses of agro-ecosystem models for simulating C and N fluxes. Sci. Total Environ. 2017, 598, 445-470. [CrossRef] [PubMed]

93. Violle, C.; Choler, P.; Borgy, B.; Garnier, E.; Amiaud, B.; Debarros, G.; Diquelou, S.; Gachet, S.; Jolivet, C.; Kattge, J.; et al. Vegetation ecology meets ecosystem science: Permanent grasslands as a functional biogeography case study. Sci. Total Environ. 2015, 534, 43-51. [CrossRef] [PubMed]

94. Confalonieri, R. CoSMo: A simple approach for reproducing plant community dynamics using a single instance of generic crop simulators. Ecol. Model. 2014, 286, 1-10. [CrossRef]

95. Natural England. Environmental Impacts of Land Management (NERR030); Natural England: York, UK, 2009.

96. Peringer, A.; Siehoff, S.; Chételat, J.; Spiegelberger, T.; Buttler, A.; Gillet, F. Past and future landscape dynamics in pasture-woodlands of the Swiss Jura Mountains under climate change. Ecol. Soc. 2013, 18, 11. [CrossRef]

97. Bullock, J.; Franklin, J.; Stevenson, M.; Silvertown, J.; Coulson, S.; Gregory, S.; Tofts, R. A plant trait analysis of responses to grazing in a long-term experiment. J. Appl. Ecol. 2001, 38, 253-267. [CrossRef]

98. Van Oijen, M.; Höglind, M. Toward a Bayesian procedure for using process-based models in plant breeding, with application to ideotype design. Euphytica 2016, 207, 627-643. [CrossRef] 
99. Van Oijen, M.; Cameron, D.; Butterbach-Bahl, K.; Farahbakhshazad, N.; Jansson, P.-E.; Kiese, R.; Rahn, K.-H.; Werner, C.; Yeluripati, J. A Bayesian framework for model calibration, comparison and analysis: Application to four models for the biogeochemistry of a Norway spruce forest. Agric. For. Meteorol. 2011, 151, 1609-1621. [CrossRef]

100. Van Oijen, M.; Reyer, C.; Bohn, F.; Cameron, D.; Deckmyn, G.; Flechsig, M.; Härkönen, S.; Hartig, F.; Huth, A.; Kiviste, A.; et al. Bayesian calibration, comparison and averaging of six forest models, using data from Scots pine stands across Europe. For. Ecol. Manag. 2013, 289, 255-268. [CrossRef]

101. Korhonen, P.; Palosuo, T.; Persson, T.; Höglind, M.; Jego, G.; Van Oijen, M.; Gustavsson, A.-M.; Belanger, G.; Virkajärvi, P. Modelling grass yields in northern climates-A comparison of three growth models for timothy. Field Crops Res. 2017, submitted.

102. Van Oijen, M. Bayesian Methods for Quantifying and Reducing Uncertainty and Error in Forest Models. Curr. For. Rep. 2017, 3, 269-280. [CrossRef]

103. Tilman, D.; Downing, J.A. Biodiversity and stability in grasslands. Nature 1994, 367, 363-365. [CrossRef]

104. Lemaire, G.; Wilkins, R.; Hodgson, J. Challenges for grassland science: Managing research priorities. Agric. Ecosyst. Environ. 2005, 108, 99-108. [CrossRef]

105. Muscardi, D.C.; Schoereder, J.H.; Sperber, C.F. Biodiversity and Ecosystem Functioning: A Conceptual Model of Leaf Litter Decomposition. In Biodiversity —The Dynamic Balance of the Planet; Grillo, O., Ed.; InTech: London, UK, 2014; ISBN 978-953-51-1315-7.

106. Van Oijen, M.; Balkovic, J.; Beer, C.; Cameron, D.R.; Ciais, P.; Cramer, W.; Kato, T.; Kuhnert, M.; Martin, R.; Myneni, R.; et al. Impact of droughts on the carbon cycle in European vegetation: A probabilistic risk analysis using six vegetation models. Biogeosciences 2014, 11, 6357-6375. [CrossRef]

107. Colwell, R.K. Biodiversity: Concepts, patterns, and measurement. In The Princeton Guide to Ecology; Princeton University Press: Princeton, NJ, USA, 2009; pp. 257-263.

108. Beynon, S.A.; Mann, D.J.; Slade, E.M.; Lewis, O.T. Species-rich dung beetle communities buffer ecosystem services in perturbed agro-ecosystems. J. Appl. Ecol. 2012, 49, 1365-1372. [CrossRef]

109. De Vries, F.T.; Bloem, J.; Quirk, H.; Stevens, C.J.; Bol, R.; Bardgett, R.D. Extensive Management Promotes Plant and Microbial Nitrogen Retention in Temperate Grassland. PLoS ONE 2012, 7, e51201. [CrossRef] [PubMed]

110. Littlewood, N.A.; Stewart, A.J.A.; Woodcock, B.A. Science into practice how can fundamental science contribute to better management of grasslands for invertebrates? Insect Conserv. Divers. 2012, 5, 1-8. [CrossRef]

111. Philippot, L.; Spor, A.; Hénault, C.; Bru, D.; Bizouard, F.; Jones, C.M.; Sarr, A.; Maron, P.-A. Loss in microbial diversity affects nitrogen cycling in soil. ISME J. 2013, 7, 1609-1619. [CrossRef] [PubMed]

112. Wachendorf, M.; Fricke, T.; Möckel, T. Remote sensing as a tool to assess botanical composition, structure, quantity and quality of temperate grasslands. Grass Forage Sci. 2017, 1-15. [CrossRef]

113. Diodato, N.; Bellocchi, G. Modelling vegetation greenness responses to climate variability in a Mediterranean terrestrial ecosystem. Environ. Monitor. Assess. 2008, 143, 147-159. [CrossRef] [PubMed]

114. Gaitán, J.J.; Bran, D.; Oliva, G.; Maestre, F.T.; Aguiar, M.R.; Jobbágy, E.; Buono, G.; Ferrante, D.; Nakamatsu, V.; Ciari, G.; et al. Plant species richness and shrub cover attenuate drought effects on ecosystem functioning across Patagonian rangelands. Biol. Lett. 2014, 10, 20140673. [CrossRef] [PubMed]

115. Balvanera, P.; Siddique, I.; Dee, L.; Paquette, A.; Isbell, F.; Gonzalez, A.; Byrnes, J.; O'Connor, M.I.; Hungate, B.A.; Griffin, J.N. Linking Biodiversity and Ecosystem Services: Current Uncertainties and the Necessary Next Steps. BioScience 2013. [CrossRef]

(C) 2018 by the authors. Licensee MDPI, Basel, Switzerland. This article is an open access article distributed under the terms and conditions of the Creative Commons Attribution (CC BY) license (http://creativecommons.org/licenses/by/4.0/). 